\title{
MISCELÁNEA
}

\section{DISTINCIÓN LEGAL ENTRE CASTELLANO Y ARAGONÉS EN 1409}

1. El 27 de abril de $\mathbf{1 4 0 9}$ se firmó en Barcelona un acuerdo aduanero entre los Reinos de Aragón y de Castilla, aquél representado por su rey Martín el Humano, y éste por los embajadores de Juan II. Dicho acuerdo, que figura copiado dentro de la ratificación del mismo verificada por Juan II ${ }^{1}$ en Tordesillas, el 4 de junio de 1409, contiene, entre sus disposiciones finales, la siguiente, objeto de esta nota:

Es concordado [...] que de los dichos capitulos, tractos et concordia se fagan dos cartas: la una escripta en lengua aragonés; la otra, escripta en lengua castellana. $E$ que amas las dichas cartas sean firmadas de los nombres del dicho senyor rey de Aragón et de los dichos enbaxadores, et signadas por notario público. $E$ que la carta escripta en aragonés quede al dicho senyor rey de Aragon; et la otra escripta en castellano lieven los dichos enbaxadores para el dicho senyor rey de Castiella.

La diversidad entre castellano y aragonés ya había sido expresamente advertida por Alfonso $\mathrm{X}^{2}$, aunque el testimonio léxico en que se apoya, no resulte muy apropiado: Regno empos el su hermano don Alfonsso, al que llamaron alla en su aragones Batallador.

1 El documento de Juan II, conservado en el Archivo de la Corona de Aragón, fue publicado por P. de Bofarull y Mascaró, en Procesos de las antiguas cortes y parlamentos de Catalunia, Aragón y Valencia..., Barcelona, 1847, I, 87-105.

2 Alfonso el Sablo, Primera Crónica General de Esparia. Ed. de R. Menendez Pidal, Madrid, 1955, 537a. 
2. A otro orden de cosas pertenece el hecho que aquí consigno. El empleo, por parte de cada Reino, de su propia lengua en la redacción de un instrumento diplomático atinente a ambos, comporta la afirmación legal de la personalidad linguística irrenunciable de cada uno de ellos.

La noticia me parece novedosa y encierra un notable interés para el conocimiento de la política linguística de los Reinos medievales. Permítaseme requerir el concurso de los investigadores de historia social y política para que saquen a luz, si existen, otras manifestaciones análogas, que pueden quedar preteridas por la importancia de las diversas informaciones (acontecimientos bélicos, noticias biográficas, datos económicos, etc.), que suministran las fuentes documentales.

3. Ignoro la suerte que haya podido correr la versión aragonesa del acuerdo de 1409. Su cotejo con la castellana permitiría -apenas habrá que decirlo- establecer los rasgos considerados como diferenciales entre el castellano y el aragonés de comienzos del siglo xv, según los propios hablantes.

En la versión castellana no faltan algunos aragonesismos gráficos (anyos, senyor, etc.), y gramaticales (era estada puesta, son estados firmados, etc.), fácilmente explicables por la procedencia geográfica del documento. Por otra parte, acorde con la esencial naturaleza castellana del mismo, merece destacarse un detalle muy particular, que se encuentra precisamente en el fragmento antes copiado. Dentro del sintagma lengua aragonés, el adjetivo ${ }^{3}$ no ha adquirido moción femenina, según una marcada resistencia histórica del castellano a tal proceso en los adjetivos terminados en -és, como es bien sabido. Mientras que en aragonés, tales adjetivos (como otros de forma etimológica única) propenden a la moción. Valga recordar cortesa, en textos más o menos teñidos de aragonesismo (Razón de amor, 91; Santa Maria Egipciaca, 378).

F. Gonzalbz Ollé

Universidad de Navarra

3 Seria posible, pero menos probable, que aragonés fuera sustantivo, 'lengua aragonesa', según se documenta líneas despues y en el testimonio antes copiado de Alfonso $X, y$, por tanto, permaneciera invariable, como aposición de lengua. 